\title{
Cytokines in Chronic Inflammatory Arthritis. V. Mutual Antagonism between Interferon-Gamma and Tumor Necrosis Factor-Alpha on HLA-DR Expression, Proliferation, Collagenase Production, and Granulocyte Macrophage Colony- stimulating Factor Production by Rheumatoid Arthritis Synoviocytes
}

\author{
Jose M. Alvaro-Gracia, Nathan J. Zvaifler, and Gary S. Firestein \\ Department of Medicine, Division of Rheumatology, University of California, San Diego, California 92103
}

\begin{abstract}
The effects of a broad array of cytokines, individually and in combination, were determined on separate functions (proliferation, collagenase production, and granulocyte macrophage colony-stimulating factor [GM-CSF] production) and phenotype (expression of class II MHC antigens) of cultured fibroblastlike RA synoviocytes. The following recombinant cytokines were used: IL-1 beta, IL-2, IL-3, IL-4, IFN-gamma, tumor necrosis factor (TNF)-alpha, GM-CSF, and macrophage colonystimulating factor (M-CSF). Only IFN-gamma induced HLADR (but not HLA-DQ) expression. TNF-alpha inhibited IFNgamma-mediated HLA-DR expression (46.7 $\pm 4.1 \%$ inhibition) and HLA-DR mRNA accumulation. This inhibitory effect was also observed in osteoarthritis synoviocytes. Only TNF-alpha and IL-1 increased synoviocyte proliferation (stimulation index 3.60 \pm 1.03 and $2.31 \pm 0.46$, respectively). IFN-gamma (but none of the other cytokines) inhibited TNF-alpha-induced proliferation ( $70 \pm 14 \%$ inhibition) without affecting the activity of IL-1. Only IL-1beta and TNF-alpha induced collagenase production (from $<0.10 \mathrm{U} / \mathrm{ml}$ to $1.10 \pm 0.15$ and $0.72 \pm 0.24$, respectively). IFN-gamma decreased TNF-alpha-mediated collagenase production (69 $\pm 19 \%$ inhibition) and GM-CSF production but had no effect on the action of IL-1. These data demonstrate mutual antagonism between IFN-gamma and TNF-alpha on fibroblast-like synoviocytes and suggest a novel homeostatic control mechanism that might be defective in RA where very little IFN-gamma is produced. (J. Clin. Invest. 1990. 86:1790-1798.) Key words: cytokine • interferon-gamma - tumor necrosis factor-alpha - synoviocyte - rheumatoid arthritis
\end{abstract}

\section{Introduction}

Synovial lining hyperplasia and destruction of extracellular matrix are characteristic histopathological findings in rheumatoid arthritis $(1,2)$. These phenomena are, in part, a consequence of increased numbers of fibroblast-like (type B) synoviocytes with a concomitant increase in their secretion of mediators involved in matrix destruction, such as prostaglandins and collagenase (3-6). The synovial cytokine milieu in the

Address reprint requests to Dr. Gary S. Firestein, University of California, San Diego, 225 Dickinson Street, H-811-G, San Diego, CA 92103.

Received for publication 19 December 1989 and in revised form 15 May 1990.

J. Clin. Invest.

(C) The American Society for Clinical Investigation, Inc.

0021-9738/90/12/1790/09 \$2.00

Volume 86, December 1990, 1790-1798 inflamed joint is thought to be influential in these changes. This notion is derived from the fact that cytokines induce a number of functional alterations in cultured synoviocytes that mimic those observed in the inflamed synovium. For instance, IL-1, tumor necrosis factor (TNF)-alpha, ${ }^{1}$ platelet-derived growth factor, and basic fibroblast growth factor, each of which is present in RA synovial fluid, (7-12) increase cultured synoviocyte proliferation (13-17) and IL-1 and TNF-alpha can stimulate the synthesis of collagenase $(18,19)$ and granulocyte macrophage colony-stimulating factor (GM-CSF) (Alvaro-Gracia, J. M., N. J. Zvaifler, and G. S. Firestein, submitted for publication) by synoviocytes. Also, cytokines are likely important in determining the surface phenotype of synoviocytes, particularly the expression of class II major histocompatibility markers. GM-CSF is a major inducer of HLA-DR expression on macrophage-like (type A) synoviocytes (20) and IFN-gamma has been shown to induce HLA-DR on cultured type B synoviocytes $(21,22)$.

Most studies on synovial cells have been performed to determine the effects of individual cytokines. However, it has become increasingly clear that these factors do not function in isolation; rather, the synovium is bathed in a mixture in which specific interactions might be important. In order to understand the role of cytokines in chronic arthritis better, we have studied the effects of a broad array of individual factors on separate functions (proliferation, collagenase production, and GM-CSF production) and phenotype (expression of class II MHC antigens) of cultured synoviocytes. We then analyzed their effects when used in combinations. As expected, IL-1 beta and TNF-alpha enhanced each other's effect on synoviocyte proliferation and collagenase production. The most striking finding, however, was mutual antagonism between TNF-alpha and IFN-gamma; TNF-alpha inhibited IFN-gamma-mediated HLA-DR induction on cultured synoviocytes while IFNgamma blocked TNF-alpha-induced proliferation and collagenase production. IFN-gamma also inhibited TNF-alpha-induced GM-CSF secretion. These data suggest a novel homeostatic control mechanism in the synovium that might be defective in RA.

\section{Methods}

Synoviocyte culture. Synovial tissues (ST) were obtained from patients with RA and osteoarthritis (OA) undergoing total hip or knee replacement surgery. Synoviocytes were isolated by collagenase digestion as previously described (23). Briefly, the tissues were minced and incu-

1. Abbreviations used in this paper: GM-CSF, granulocyte macrophage colony-stimulating factor; M-CSF, macrophage CSF; MFC, mean fluorescence channel; OA, osteoarthritis; ST, synovial tissue; TNF, tumor necrosis factor. 
bated with $2 \mathrm{mg} / \mathrm{ml}$ collagenase (Worthington Biochemical Corp., Freehold, NJ) in serum-free Dulbecco's modified Eagle's medium (DMEM) (Gibco Laboratories, Grand Island, NY) for $2 \mathrm{~h}$ at $37^{\circ} \mathrm{C}$, filtered through a nylon mesh, extensively washed, and cultured in DMEM supplemented with $10 \%$ FCS (Gibco; endotoxin content $<0.006 \mathrm{ng} / \mathrm{ml}$ ), penicillin, streptomycin, and L-glutamine (medium) in a humidified $5 \% \mathrm{CO}_{2}$ atmosphere. After overnight culture, nonadherent cells were removed and adherent cells were cultivated in DMEM plus $10 \%$ FCS. At confluence, cells were trypsinized, split at a 1:3 ratio, and recultured in medium. Synoviocytes were used from passages three through seven in these experiments, during which time they were a homogeneous population of fibroblast-like synoviocytes ( $<1 \%$ CDI lb positive, FC $\gamma$ RII,$<1 \%$ phagocytic, and $<1 \%$ receptorpositive).

Reagents. Recombinant hIL-1 beta (sp act $5 \times 10^{8} \mathrm{U} / \mathrm{mg}$, purity $>95 \%$ ) was purchased from Amgen Biologicals (Thousand Oaks, CA). Recombinant hIFN-gamma (sp act $2 \times 10^{7} \mathrm{U} / \mathrm{mg}$, purity $>98 \%$ ) and hGM-CSF (sp act $10^{8} \mathrm{U} / \mathrm{mg}$, purity $>95 \%$ ) were a gift from Amgen Biologicals. Recombinant hIL-3 (sp act $10^{8} \mathrm{CFU} / \mathrm{mg}$, purity $>95 \%$ ) was purchased from Genzyme Corp. (Cambridge, MA). Recombinant hIL-4 (sp act $10^{8} \mathrm{U} / \mathrm{mg}$, purity $>95 \%$ ), was obtained from Immunex Corp. (Seattle, WA). Recombinant hIL-6 (sp act $5 \times 10^{9} \mathrm{U} / \mathrm{mg}$, purity $>95 \%$ ) was a gift from Dr. Martin Lotz (U.C.S.D. Medical Center, San Diego, CA). Recombinant hIL-2 (sp act $3 \times 10^{6} \mathrm{U} / \mathrm{mg}$, purity $>95 \%$ ) was obtained from Cetus Corp. (Emeryville, CA) and recombinant hM-CSF (CSF-1) (sp act $7 \times 10^{7} \mathrm{U} / \mathrm{mg}$, purity $\left.>95 \%\right)$ was a gift from Dr. R. Halenbeck, Cetus Corp. Recombinant hTNF-alpha (sp act 5 $\times 10^{7} \mathrm{U} / \mathrm{mg}$, purity $>95 \%$ ) was provided by Genentech Inc. (South San Francisco, CA). In each case, the final concentration of LPS in culture after dilution of recombinant cytokine was $<0.005 \mathrm{ng} / \mathrm{ml}$. The maximum concentrations of cytokines used were generally determined from standard biological assays (e.g., IL-2 in cytotoxic T lymphocyte line (CTLL) assay, GM-CSF in HLA-DR induction assay on monocytes, M-CSF in CFU assay using murine bone marrow, etc.). The range of concentrations tested in the various assays were: IL-1beta (1-100 U/ml), IL-2 (1-100 ng/ml), IL-3 (1-100 U/ml), IL-4 (1-100 $\mathrm{U} / \mathrm{ml})$, TNF-alpha (1-100 ng/ml), IFN-gamma (1-100 U/ml), GMCSF (8-800 U/ml), and M-CSF (10-1,000 U/ml). Polymyxin B (7,900 $\mathrm{U} / \mathrm{mg}$ ) was purchased from Sigma Chemical Co. (St. Louis, MO).

$H L A-D R$ and $D Q$ surface expression. HLA-DR and DQ expression was assayed by immunofluorescence and FACS analysis. HLA-DR was detected with the MAb SC2 $\left(\mathrm{IgG}_{2}\right.$, kindly provided by Dr. Robert Fox, Scripps Clinic Research Foundation, La Jolla, CA); HLA-DQ was detected with the MAb Leu $10\left(\mathrm{IgG}_{1}\right.$, Becton Dickinson Immunocytometry Systems, Mountain View, CA). Synoviocytes $\left(1-2 \times 10^{5}\right)$ were cultured in 6-well plastic dishes (Costar Data Packaging Corp., Cambridge, MA) for $3 \mathrm{~d}$ in DMEM-10\% FCS and cytokines. Cells were harvested by brief trypsinization and stained with the corresponding $\mathrm{MAb}$ as described (24). The brief trypsinization does not affect detection of surface HLA-DR or DQ (data not shown). Phycoerythrin-conjugated $\mathrm{Fab}_{2}$ anti-mouse IgG (Tago Inc., Burlingame, CA) was used as secondary antibody instead of FITC-conjugated to avoid problems with the green autofluorescence exhibited by synoviocytes. FACS analysis was performed in a cytofluorograph IIs (Ortho Diagnostic Systems Inc., Raritan, NJ). 5,000 cells were analyzed from each sample adjusting the fluorescence gain so that approximately $5 \%$ of the cells of the sample with greatest fluorescence were positive in the highest fluorescence channel. The results are presented as absolute or relative mean fluorescence channel (MFC) of total cells. The relative MFC $=$ absolute $\mathrm{MFC}_{\text {cytokine/absolute }} \mathrm{MFC}_{\text {medium }}$.

$m R N A$ analysis. Northern blot analysis was performed as previously described (20). Briefly, total cytoplasmic RNA was isolated from 1-2 $\times 10^{6}$ synoviocytes cultured for $48 \mathrm{~h}$ with cytokines using the acid guanidine phenol chloroform protocol (25). $20 \mu \mathrm{g}$ of RNA were run on a $1.2 \%$ agarose-formaldehyde gel and blotted onto a nylon membrane (Schleicher \& Schuell, Inc., Keene, NH). The HLA-DR beta chain probe (kindly provided by Dr. Per Peterson, Scripps Clinic Research Foundation, La Jolla, CA) was radiolabeled with [ $\left.{ }^{32} \mathrm{P}\right] \mathrm{dCTP}$
(Amersham Corp., Arlington Heights, IL) by the random primer method (Bethesda Research Laboratories, Gaithersburg, MD) and the filter was hybridized overnight at $42^{\circ} \mathrm{C}$. The filter was washed and exposed with Kodak X-AR film at $-20^{\circ} \mathrm{C}$ and an intensifying screen. Ethidium bromide staining of ribosomal RNA was used as control for the amount of RNA loaded in the different lanes.

Proliferation. Subconfluent synoviocytes were passed into flat-bottom 96-well dishes (Linbro, McClean, VA) at $10^{4}$ cells/well. After overnight incubation, cells were cultured in DMEM containing $10 \%$ FCS and cytokines for $3 \mathrm{~d} .1 \mu \mathrm{Ci}$ of $\left[{ }^{3} \mathrm{H}\right]$ thymidine (Amersham) was then added to the cultures and the cells were incubated for 24 more $h$. At the end of the incubation period, cells were washed with PBS, detached with $0.1 \%$ trypsin-0.04\% EDTA, and harvested onto glassfiber filters using a microharvesting device (Otto Hiller Co., Madison, WI). Incorporated radioactivity was measured using a liquid scintillation counter (Southern Biotechnology Associates, Birmingham, AL). The results are shown either as total cpm or as stimulation index $=\mathrm{cpm}_{\text {cytokine }} / \mathrm{cpm}_{\text {medium }}$. In some experiments, cells were starved in $1 \%$ FCS for $3 \mathrm{~d}$ and the proliferation assay was subsequently performed in this medium.

Collagenase activity. Synoviocytes were plated in 24-well dishes at $1.5 \times 10^{5}$ cells/well in DMEM-10\% FCS. After overnight incubation the medium was replaced with $0.4 \mathrm{ml}$ of $1 \%$ FCS DMEM plus cytokine. Supernatants were collected after $3 \mathrm{~d}$ of culture and stored at $-70^{\circ} \mathrm{C}$ until assayed. Collagenase activity was measured in these supernatants after treatment with trypsin (Sigma) $100 \mu \mathrm{g} / \mathrm{ml}$ for $20 \mathrm{~min}$ followed by a fivefold excess of soybean trypsin inhibitor to activate latent collagenase. An indirect ELISA, according to the method of Yoshioka et al. (26), was used. Briefly, flat-bottom 96-well dishes (Linbro) were coated with type I calf skin collagen (Sigma) for a minimum of $7 \mathrm{~d}$ at $4^{\circ} \mathrm{C}$. The plates were washed with PBS and samples were diluted 1 to 2 in a Tris- $\mathrm{HCl}$ buffer (26) and incubated for $1 \mathrm{~h}$ at $37^{\circ} \mathrm{C}$. The undigested collagen was detected with affinity-purified goat antihuman type I collagen antibody (Southern Biotechnology) followed by an alkaline phosphatase-labeled affinity-purified rabbit anti-goat IgG antibody (Sigma). Para-nitrophenyl-phosphate (Sigma) $1 \mathrm{mg} / \mathrm{ml}$ was used as substrate and the ODs were determined at $405 \mathrm{~nm}$ in an ELISA reader (Bio-Rad Laboratories, Richmond, CA).

GM-CSF assay. GM-CSF was assayed by Dr. Kenneth Kaushansky and Dr. Christopher B. Brown (University of Washington, Seattle, WA) using a specific solid-phase ELISA as previously described (27).

Statistics. Statistical analysis was performed using the Student's $t$ test.

\section{Results}

\section{$H L A-D R$ and $H L A-D Q$ expression on cultured synoviocytes}

Effect of individual cytokines. Initial experiments compared the effect of several individual cytokines on HLA-DR surface expression on synoviocytes (third to seventh passage) after $3 \mathrm{~d}$ incubation. The results were analyzed by FACS. Unstimulated cultured synoviocytes had no detectable class II MHC antigens (DR or DQ) on their surface. As has been noted by others (21, 22), IFN-gamma was a potent inducer of HLA-DR. None of the other cytokines tested altered DR expression, including several mediators that induce class II MHC antigens on other cell types (e.g., TNF-alpha, GM-CSF, and IL-4) (see Fig. 1). None of the cytokines (including IFN-gamma) induced HLADQ expression (data not shown).

Cytokine interactions. The ability of other cytokines to modulate the HLA-DR-inducing effect of IFN-gamma was then studied. In these experiments, the other individual cytokines were added to synoviocytes simultaneously with IFNgamma. IL-1beta, IL-2, IL-3, IL-4, GM-CSF, and M-CSF had 


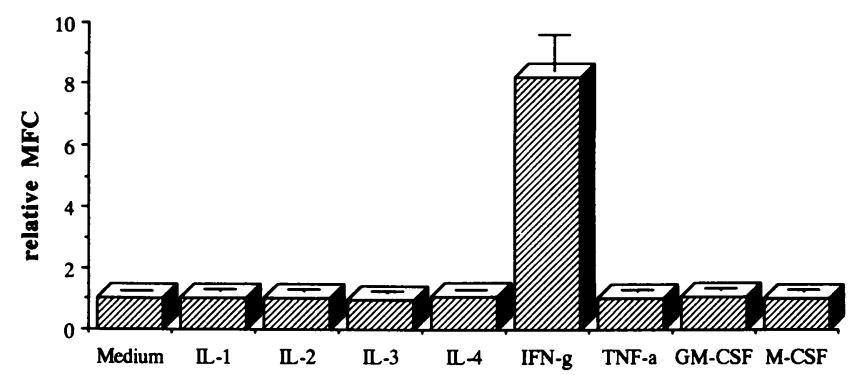

Figure 1. HLA-DR induction by cytokines on RA type B synoviocytes. Third to seventh passage synoviocytes were incubated for $72 \mathrm{~h}$ in DMEM-10\% FCS and cytokines (IL-1 beta $100 \mathrm{U} / \mathrm{ml}$; IL-2 100 ng/ml; IL-3 100 U/ml; IL-4 100 U/ml; IFN-gamma 100 U/ml; TNFalpha $100 \mathrm{ng} / \mathrm{ml}$; GM-CSF $800 \mathrm{U} / \mathrm{ml}$; and M-CSF 1,000 U/ml). Cells were analyzed for HLA-DR expression by FACS. Results are shown as relative MFC $\pm \mathrm{SEM}$ (see Methods); $n=9$ for medium, IFN-gamma and TNF-alpha; $n=5$ for IL-4 and GM-CSF; $n=3$ for other cytokines.

no effect on the IFN-gamma-induced HLA-DR expression (data not shown). However, TNF-alpha significantly inhibited the IFN-gamma-mediated HLA-DR expression on synoviocytes $(49.3 \pm 5.1 \%$ inhibition, $n=6, P<0.001)$ (see Fig. 2). This inhibitory effect was not due to contaminating endotoxin since no difference was detected in experiments performed in the presence of polymyxin B $(16 \mu \mathrm{g} / \mathrm{ml})$ (data not shown). To determine if the effects of IFN-gamma and TNF-alpha on HLA-DR expression were unique to RA synoviocytes, the response of cells isolated from rheumatoid $(n=6)$ and osteoarthritic $(n=5)$ synovia were compared. Fig. 2 shows that both groups behaved similarly. A representative dose response for the effect of TNF-alpha on various concentrations of IFNgamma is shown in Fig. $3 \mathrm{~A}$. The inhibitory effect was not simply due to delayed kinetics of DR expression since inhibition was observed within $1 \mathrm{~d}$ and persisted for at least $6 \mathrm{~d}$ (see Fig. $3 \mathrm{~B}$ ). Because of recent interest in the role of GM-CSF on synovial macrophage HLA-DR expression $(20,28)$, we tested GM-CSF in combination with several other cytokines. Neither GM-CSF alone nor in combination with TNF-alpha, M-CSF, or IL-4 induced HLA-DR expression on synoviocytes (data not shown).

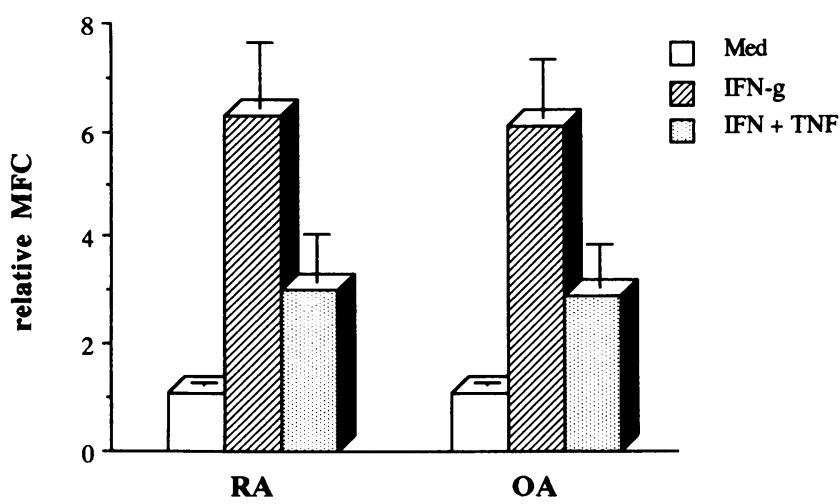

Figure 2. Inhibitory effect of TNF-alpha $(50 \mathrm{ng} / \mathrm{ml})$ on IFN-gamma $(100 \mathrm{U} / \mathrm{ml})$ induced synoviocyte HLA-DR expression. RA $(n=6)$ and OA $(n=5)$ synoviocytes (third to seventh passage) were incubated for $72 \mathrm{~h}$ in medium with or without cytokines.
A

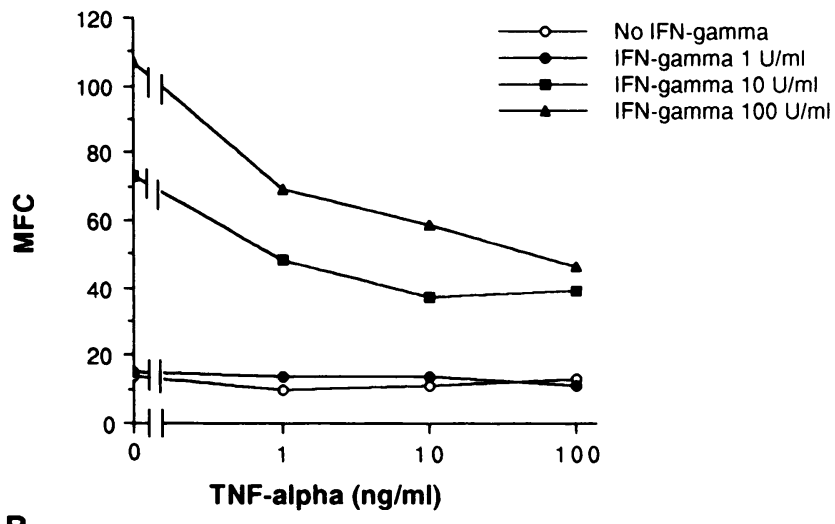

B

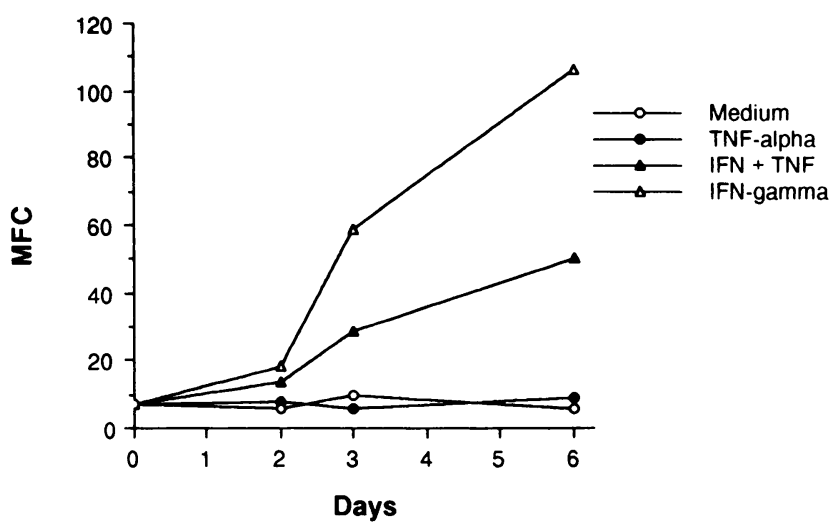

Figure 3. Dose response and time course of TNF-alpha inhibition of IFN-gamma-induced RA synoviocyte HLA-DR expression. ( $A$ ) Synoviocytes were cultured for $72 \mathrm{~h}$ in various concentrations of IFNgamma and TNF-alpha and analyzed for HLA-DR expression by FACS. (B) Synoviocytes were incubated for various times in medium, IFN-gamma $(100 \mathrm{U} / \mathrm{ml})$ and/or TNF-alpha $(50 \mathrm{ng} / \mathrm{ml})$. One representative experiment is shown in each panel $(n=2)$.

Role of prostaglandins in TNF-alpha inhibition of IFNgamma effect. TNF-alpha induces $\mathrm{PGE}_{2}$ production by synoviocytes (19) and this eicosanoid is known to inhibit HLA-DR expression on various cell types (29). For that reason, we studied a possible role of prostaglandins in TNF-alpha inhibition of IFN-gamma-mediated HLA-DR expression. Synoviocytes were incubated with both cytokines in the presence of $10^{-5} \mathrm{M}$ indomethacin. No alteration in the inhibitory effect of TNFalpha was observed (Fig. 4), suggesting that de novo prostaglandin synthesis is not involved. The fact that IL- 1 beta (which also increases prostaglandin synthesis by synoviocytes) did not affect IFN-gamma action also argues against a role for prostaglandins.

Sequential addition of IFN-gamma and TNF-alpha. Sequential addition experiments demonstrated that the inhibitory effect of TNF-alpha on HLA-DR induction only occurred when synoviocytes were exposed to IFN-gamma and TNFalpha simultaneously. Fig. $5 \mathrm{~A}$ shows a representative experiment $(n=3)$ in which synoviocytes preincubated for $12 \mathrm{~h}$ with TNF-alpha, washed, and then recultured in IFN-gamma alone had normal HLA-DR induction. Similarly, when synoviocytes were preincubated with IFN-gamma for $12 \mathrm{~h}$, washed, and 


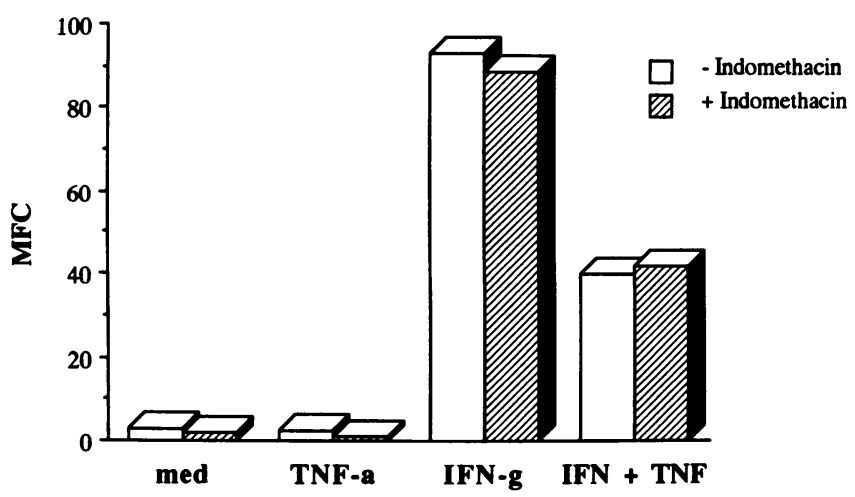

Figure 4. Effect of indomethacin on TNF-alpha inhibition of IFNgamma-mediated synoviocyte HLA-DR expression. RA synoviocytes were cultured for $72 \mathrm{~h}$ in medium, IFN-gamma (100 U/ml), TNFalpha $(50 \mathrm{ng} / \mathrm{ml})$, or both. Cultures were incubated in the presence or absence of indomethacin $\left(10^{-5} \mathrm{M}\right)$. One representative experiment is shown $(n=3)$.

then treated with TNF-alpha, HLA-DR induction was not inhibited (data not shown). Addition of TNF-alpha at various time points during continuous IFN-gamma stimulation was inhibitory only in the first $24 \mathrm{~h}$ of IFN-gamma treatment ( $n$ 3) (Fig. $5 B$ ).

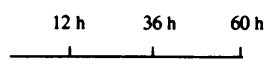

\begin{tabular}{cc}
\multicolumn{2}{c}{$\mathbf{m}$} \\
\hline $\mathbf{m}_{\perp}$ & $\mathbf{I}$ \\
\hline $\mathbf{T}$, & $\mathbf{I}$ \\
\hline $\mathbf{m}_{\perp}$ & $\mathbf{T}$ \\
\hline $\mathbf{m}_{\perp}$ & $\mathbf{I}+\mathbf{T}$ \\
\hline $\mathbf{T}$ & $\mathbf{I}+\mathbf{T}$ \\
\hline
\end{tabular}

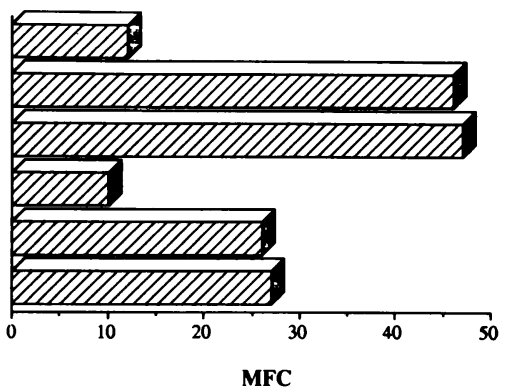

$\mathbf{A}$

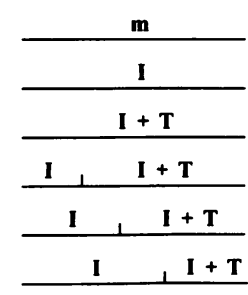

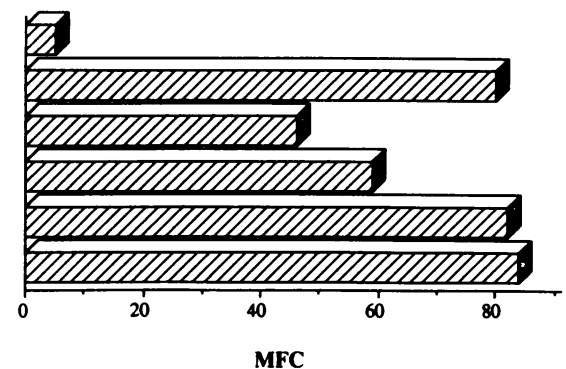

Figure 5. Effect of the sequential addition of IFN-gamma $(100 \mathrm{U} / \mathrm{ml})$ $(I)$ and TNF-alpha $(50 \mathrm{ng} / \mathrm{ml})(T)$ on synoviocyte HLA-DR expression. $(A)$ Preincubation with TNF-alpha. Synoviocytes were cultured for $12 \mathrm{~h}$ in the presence of medium $(m)$ or TNF-alpha and then washed. The synoviocytes were cultured for an additional $48 \mathrm{~h}$ with IFN-gamma and/or TNF-alpha. Cells were then analyzed for HLADR expression by FACS. (B) Addition of TNF-alpha at various time points after IFN-gamma. Synoviocytes were cultured for $60 \mathrm{~h}$ with medium alone or with $100 \mathrm{U} / \mathrm{ml}$ of IFN-gamma. TNF-alpha was added at various times without removing the IFN-gamma. HLA-DR was then measured by FACS.
A

B

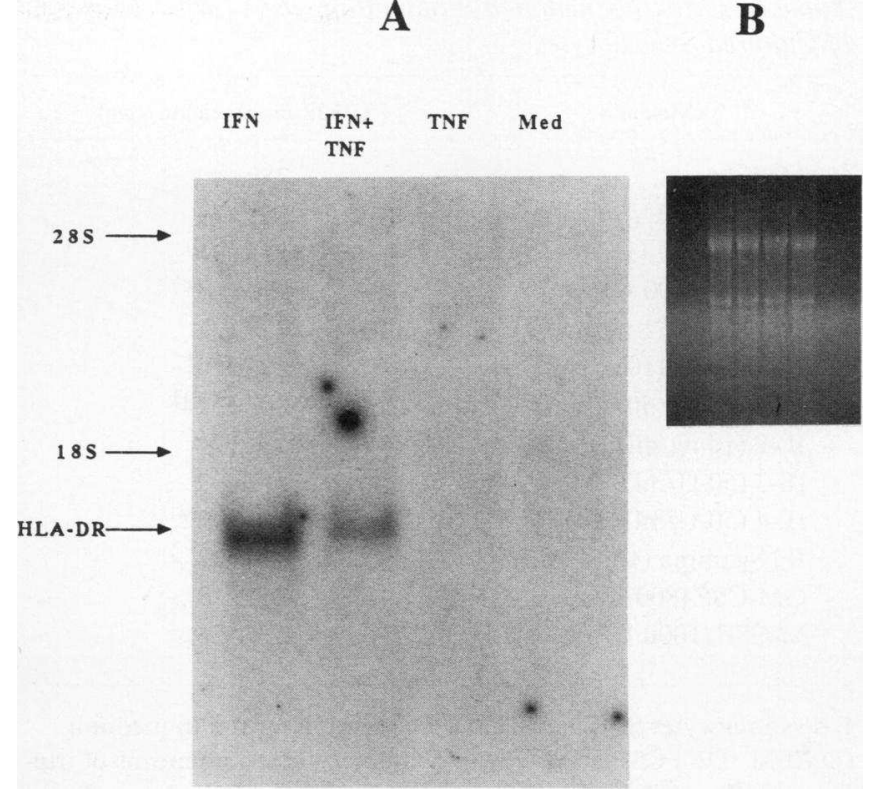

Figure 6. Inhibitory effect of TNF-alpha on IFN-gamma-induced synoviocyte HLA-DR beta chain mRNA accumulation. $(A)$ RA synoviocytes were cultured for $72 \mathrm{~h}$ in medium, IFN-gamma (100 $\mathrm{U} / \mathrm{ml}$ ), TNF-alpha $(50 \mathrm{ng} / \mathrm{ml})$, or both. Total cytoplasmic RNA was isolated and assayed by Northern blot analysis. $20 \mu \mathrm{g}$ of RNA was loaded in each lane. $(B)$ Ethidium bromide staining of ribosomal RNA was used as control for the amount of RNA loaded.

Effect of TNF-alpha on HLA-DR MRNA accumulation. Northern blot analysis was performed to study the mechanism of TNF-alpha inhibition of HLA-DR induction. Cytoplasmic RNA prepared from synoviocytes cultured in medium, IFNgamma, TNF-alpha, or IFN-gamma plus TNF-alpha for $2 \mathrm{~d}$ was assayed for HLA-DR mRNA. Fig. 6 shows that TNFalpha inhibited HLA-DR mRNA accumulation in IFNgamma-treated cells, indicating that the effect is likely pretranslational.

IFN-gamma/TNF-alpha combination is not cytotoxic. $\mathrm{Cy}-$ totoxicity induced by a combination of TNF-alpha and IFNgamma has been reported in human umbilical vein endothelial cells (30). To address the possibility that a similar mechanism could be involved in the inhibitory effect of TNF-alpha on IFN-gamma function, we studied the influence of TNF-

Table I. TNF-alpha/IFN-gamma Is Not Cytotoxic

\begin{tabular}{llcc}
\hline & & Cells $\times 10^{-5}$ & \% viable \\
\hline ST1 & Medium & 1.25 & 98.7 \\
& TNF/IFN & 1.20 & 98.8 \\
ST2 & Medium & 1.17 & 99.4 \\
& TNF/IFN & 1.18 & 99.1 \\
ST3 & Medium & 1.15 & 98.6 \\
& TNF/IFN & 1.16 & 97.8 \\
& & & \\
\hline
\end{tabular}

$10^{5}$ synoviocytes from three separate RA ST were cultured for $72 \mathrm{~h}$ in the presence of medium alone or TNF-alpha $(100 \mathrm{ng} / \mathrm{ml})$ plus IFN-gamma $(100 \mathrm{U} / \mathrm{ml})$. Cells were counted in a hemocytometer and viability assessed by trypan blue dye exclusion. 
Table II. Cytokine-mediated Proliferation of Cultured Synoviocytes

\begin{tabular}{lc}
\multicolumn{1}{c}{ Cytokine } & {$\left[{ }^{3} \mathrm{H}\right] \mathrm{TdR}$ incorporation $(\mathrm{cpm})$} \\
\hline Medium & $259 \pm 40$ \\
IL-1beta $(1 \mathrm{U} / \mathrm{ml})$ & $289 \pm 32$ \\
IL-lbeta $(10 \mathrm{U} / \mathrm{ml})$ & $325 \pm 31$ \\
IL-1beta $(100 \mathrm{U} / \mathrm{ml})$ & $558 \pm 18^{*}$ \\
TNF-alpha $(1 \mathrm{ng} / \mathrm{ml})$ & $300 \pm 22$ \\
TNF-alpha $(10 \mathrm{ng} / \mathrm{ml})$ & $805 \pm 70^{\ddagger}$ \\
TNF-alpha $(50 \mathrm{ng} / \mathrm{ml})$ & $1,208 \pm 214^{\ddagger}$ \\
IL-2 $(10 \mathrm{ng} / \mathrm{ml})$ & $232 \pm 22$ \\
IL-3 $(50 \mathrm{U} / \mathrm{ml})$ & $273 \pm 32$ \\
IL-4 $(50 \mathrm{U} / \mathrm{ml})$ & $247 \pm 10$ \\
IFN-gamma $(100 \mathrm{U} / \mathrm{ml})$ & $280 \pm 37$ \\
GM-CSF $(800 \mathrm{U} / \mathrm{ml})$ & $242 \pm 19$ \\
M-CSF $(1000 \mathrm{U} / \mathrm{ml})$ & $275 \pm 35$ \\
\end{tabular}

RA synoviocytes (third passage) were cultured for $4 \mathrm{~d}$ in medium (DMEM 10\% FCS) alone or with cytokine. Values are means of triplicate cultures \pm SEM. One representative experiment is shown. Each cytokine was tested three to seven times in separate experiments. ${ }^{*} P<0.05,{ }^{\ddagger} P<0.001$, compared to medium.

alpha/IFN-gamma on synoviocyte viability. As shown in Table I, the combination of the two cytokines was not toxic to synoviocytes after a 72 -h exposure.

\section{Proliferation of cultured synoviocytes}

Effect of individual cytokines. Cytokines were tested for their ability to induce proliferation of cultured synoviocytes. Table II shows a representative experiment. TNF-alpha consistently increased tritiated thymidine uptake by cultured synoviocytes (stimulation index $=3.60 \pm 1.03, n=7, P<0.001$ ). In four of seven cases, IL-1 beta also stimulated synoviocyte DNA synthesis (stimulation index $=2.31 \pm 0.46, P<0.05$ ). However, little or no stimulation was observed in cells from three other RA tissues studied. In general, IFN-gamma had no effect on DNA synthesis (stimulation index $=1.12 \pm 0.14, n=7, P$ $>0.1$ ), although in two of seven samples there was a modest increase in tritiated thymidine uptake. IL-2 $(1-100 \mathrm{ng} / \mathrm{ml})$, IL-3 (1-100 U/ml), IL-4 (1-100 U/ml), GM-CSF (8-800 $\mathrm{U} / \mathrm{ml}$ ), and $\mathrm{M}-\mathrm{CSF}(10-1,000 \mathrm{U} / \mathrm{ml})$ did not alter synoviocyte tritiated thymidine incorporation. The results were similar with RA and OA synoviocytes (data not shown).

Cytokine interactions. The effect of different cytokine combinations on synoviocyte proliferation was evaluated. IL- 1 and TNF-alpha had an additive effect (see Table III for a representative experiment). The most novel finding was the marked inhibition of TNF-alpha-induced proliferation by IFN-gamma (70 $\pm 14 \%$ inhibition, $n=6, P=0.002$ ) (see Table IV, experiment 1 , for a representative experiment). The inhibitory effect of IFN-gamma on TNF-alpha was also observed when cells were starved in $1 \%$ FCS for $3 \mathrm{~d}$ before the addition of cytokines (see Table IV, experiment 2, for a representative experiment). It is interesting that IFN-gamma did not inhibit the proliferative action of IL-1 (see Table IV). A representative dose response of IFN-gamma-mediated inhibition of synoviocyte proliferation is shown in Table IV, experiment 3. IL-2 (100 $\mathrm{ng} / \mathrm{ml}), \mathrm{IL}-3$ (100 U/ml), IL-4 (100 U/ml), GM-CSF (800
Table III. TNF-alpha and IL-1beta Interaction on Cultured Synoviocyte Proliferation

\begin{tabular}{lc}
\multicolumn{1}{c}{ Cytokine } & {$\left[{ }^{3} \mathrm{H}\right] \mathrm{TdR}$ incorporation $(\mathrm{cpm})$} \\
\hline Medium & $372 \pm 45$ \\
IL-1 beta & $1,087 \pm 117$ \\
TNF-alpha & $1,218 \pm 79$ \\
IL-1 beta + TNF-alpha & $2,207 \pm 34^{*}$ \\
\hline
\end{tabular}

RA synoviocytes (fifth passage) were cultured for $4 \mathrm{~d}$ in medium (DMEM 10\% FCS) alone or with cytokine (IL-1 beta $50 \mathrm{U} / \mathrm{ml}$; TNFalpha $50 \mathrm{ng} / \mathrm{ml}$ ). Values are means of triplicate cultures \pm SEM. One representative experiment $(n=3)$ is shown.

* $P<0.001$ compared to TNF-alpha.

$\mathrm{U} / \mathrm{ml})$, and $\mathrm{M}-\mathrm{CSF}(1,000 \mathrm{U} / \mathrm{ml})$ had no effect on the proliferative activity of IL-1 or TNF-alpha (data not shown).

Role of prostaglandins in IFN-gamma inhibition of TNFalpha effect. $\mathrm{PGE}_{2}$ can inhibit cellular proliferation (31) and culturing the cells in the presence of indomethacin enhances the proliferative effects of TNF-alpha and IL-1 $(14,17)$, perhaps reflecting the capacity of these two cytokines to induce $\mathrm{PGE}_{2}$ production (17-19). To evaluate a possible role of prostaglandins in the inhibitory effect of IFN-gamma, synoviocytes were cultured in the presence of cytokines plus or minus indomethacin. As expected, indomethacin $\left(10^{-5} \mathrm{M}\right)$ increased the proliferation of TNF-alpha-stimulated synoviocytes; however, it did not modulate IFN-gamma inhibition of the TNF-alpha effect (see Table $\mathrm{V}$ for a representative experiment).

Table IV. Inhibition of TNF-alpha-induced Synoviocyte Proliferation by IFN-gamma

\begin{tabular}{lcc}
\hline \multicolumn{1}{c}{ Cytokine } & \multicolumn{2}{c}{$\left[{ }^{3} \mathrm{H}\right] \mathrm{TdR}$ incorporation (cpm) } \\
\hline & Exp. 1 & Exp. 2 \\
Medium & $259 \pm 40$ & $770 \pm 110$ \\
IFN-gamma & $281 \pm 33$ & $990 \pm 240$ \\
TNF-alpha & $1,208 \pm 214$ & $1,480 \pm 70$ \\
TNF-alpha + IFN-gamma & $279 \pm 95^{*}$ & $800 \pm 202^{\ddagger}$ \\
IL-1beta & $558 \pm 18$ & $\mathrm{ND}$ \\
IL-1beta + IFN-gamma & $510 \pm 35$ & $\mathrm{ND}$ \\
\multicolumn{2}{c}{} & \\
Medium & & $1,126 \pm 71$ \\
TNF-alpha & & $2,062 \pm 40$ \\
TNF-alpha + IFN-gamma $(1 \mathrm{U} / \mathrm{ml})$ & $1,845 \pm 159$ \\
TNF-alpha + IFN-gamma $(10 \mathrm{U} / \mathrm{ml})$ & $1,233 \pm 186^{\ddagger}$ \\
TNF-alpha + IFN-gamma $(100 \mathrm{U} / \mathrm{ml})$ & $945 \pm 130^{*}$ \\
IFN-gamma (100 U/ml) & $980 \pm 50$ \\
& & \\
\hline
\end{tabular}

Exp. 1 and 2. Synoviocytes were cultured for $4 \mathrm{~d}$ in medium alone or with cytokine (IL-l beta $50 \mathrm{U} / \mathrm{ml}$; TNF-alpha $50 \mathrm{ng} / \mathrm{ml}$; IFN-gamma $100 \mathrm{U} / \mathrm{ml}$ ). Experiment 1 was performed in DMEM-10\% FCS and experiment 2 was carried out in DMEM-1\% FCS. Representative experiments are shown ( $n=3$ in $10 \% \mathrm{FCS}$ and $n=3$ in $1 \% \mathrm{FCS})$.

Exp. 3. Dose response in DMEM-10\% FCS. ${ }^{\S} \mathrm{TNF}$-alpha $50 \mathrm{ng} / \mathrm{ml}$. Values are means of triplicate cultures \pm SEM.

${ }^{*} P<0.001 ;{ }^{\ddagger} P<0.01$ compared with TNF-alpha. 
Table V. Effect of Indomethacin on Cytokine-induced Synoviocyte Proliferation

\begin{tabular}{lcc}
\hline & \multicolumn{2}{c}{$\left[{ }^{3} \mathrm{H}\right] \mathrm{TdR}$ incorporation $(\mathrm{cpm})$} \\
\cline { 2 - 3 } \multicolumn{1}{c}{ Cytokine } & -Indomethacin & +Indomethacin \\
\hline Medium & $490 \pm 91$ & $538 \pm 59$ \\
TNF-alpha & $1,954 \pm 256$ & $2,670 \pm 240$ \\
IFN-gamma & $570 \pm 143$ & $585 \pm 210$ \\
TNF-alpha + IFN-gamma & $1,130 \pm 210$ & $1,010 \pm 320$
\end{tabular}

Synoviocytes (third passage) were cultured for $4 \mathrm{~d}$ in medium (DMEM 10\% FCS) alone or cytokines (IFN-gamma $100 \mathrm{U} / \mathrm{ml}$; TNFalpha $50 \mathrm{ng} / \mathrm{ml}$ ) in the presence or absence of indomethacin $10^{-5} \mathrm{M}$. Values are means of triplicate cultures \pm SEM. One representative experiment is shown $(n=4)$.

\section{Collagenase activity in supernatants of cultured synoviocytes}

Effect of individual cytokines. Collagenase activity in supernatants of synoviocytes cultured in the presence of different cytokines was measured by an indirect ELISA. Our data (see Fig. 7 for a representative experiment) confirm that IL-1 and TNF-alpha increase synoviocyte production of collagenase (from $<0.10 \mathrm{U} / \mathrm{ml}$ to $1.10 \pm 0.15, n=5, P=0.003$, and $0.72 \pm 0.24, n=6, P=0.048$, respectively) and demonstrate the narrow spectrum of cytokines with this capacity. IL-2, 1-100 $\mathrm{ng} / \mathrm{ml}$; IL-3, 1-100 U/ml; IL-4, 1-100 U/ml; IFN-gamma, 1-100 U/ml; GM-CSF, 8-800 U/ml; and M-CSF, 10-1,000 $\mathrm{U} / \mathrm{ml}$, did not enhance collagenase activity.

Cytokine interactions. To study the possibility that other cytokines might interfere with the increase in collagenase activity in the supernatants of IL-1 and TNF-alpha-treated synoviocytes, we analyzed the effect of several combinations. Table VI shows that IL-1beta and TNF-alpha together had a less than additive effect. It is interesting that IFN-gamma decreased TNF-alpha-mediated collagenase activity $(69 \pm 19 \%$ inhibition, $n=3, P=0.029$ ) but had no effect on the action of IL-1 (see Table VI for a representative experiment). Studies are currently in progress to determine if the decrease in collage-

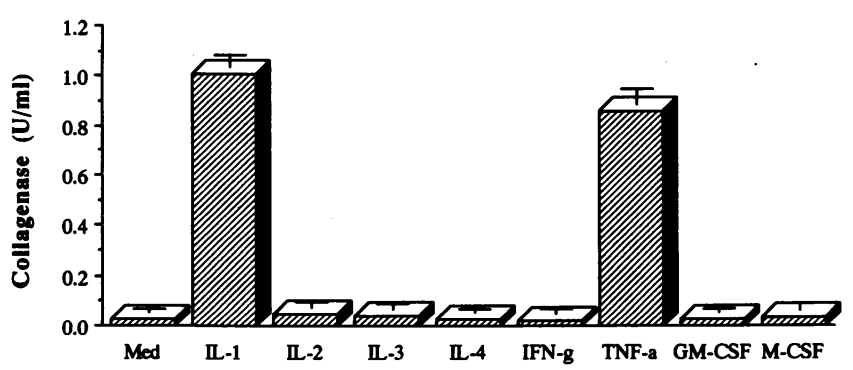

Figure 7. Collagenase activity in supernatants of cytokine stimulated RA synoviocytes. Synoviocytes (third passage) were cultured for $72 \mathrm{~h}$ in DMEM-1\% FCS and the following cytokines: IL-1 beta (100 $\mathrm{U} / \mathrm{ml})$, IL-2 $(50 \mathrm{ng} / \mathrm{ml})$, IL-3 (100 U/ml), IL-4 (100 U/ml), IFNgamma (100 U/ml), TNF-alpha (50 ng/ml), GM-CSF (800 U/ml), and $\mathrm{M}-\mathrm{CSF}(1,000 \mathrm{U} / \mathrm{ml})$. The supernatants were harvested and assayed for collagenase activity by an indirect ELISA. Results are indicated as units $/ \mathrm{ml}$ per $10^{6}$ cells. One representative experiment is shown ( $n=3$ to 7 for each cytokine).
Table VI. Cytokine Interactions on Synoviocyte Collagenase Production

\begin{tabular}{lc}
\hline \multicolumn{1}{c}{ Cytokine } & Collagenase $(\mathrm{U} / \mathrm{ml})$ \\
\hline Medium & $\leq 0.10$ \\
IL-1 beta & $0.99 \pm 0.01$ \\
TNF-alpha & $0.36 \pm 0.03$ \\
IL-1beta + TNF-alpha & $1.11 \pm 0.04$ \\
TNF-alpha + IFN-gamma & $\leq 0.10^{*}$ \\
IL-1 beta + IFN-gamma & $1.09 \pm 0.09$ \\
\hline
\end{tabular}

RA synoviocytes (fourth passage) were cultured for $3 \mathrm{~d}$ in

DMEM-1\% FCS and cytokines (IL-1 $50 \mathrm{U} / \mathrm{ml}$; TNF-alpha $50 \mathrm{ng} / \mathrm{ml}$; IFN-gamma $100 \mathrm{U} / \mathrm{ml}$ ). The supernatants were harvested and assayed for collagenase by indirect ELISA. Values are means of triplicate wells \pm SEM. One representative experiment is shown $(n=3)$.

* $P<0.01$ compared with TNF-alpha.

nase activity is due to diminished collagenase production or increased tissue inhibitor of metalloproteinases production. IL-2, IL-3, IL-4, GM-CSF, and M-CSF had no effect on TNFalpha or IL-1 mediated-collagenase production (data not shown).

\section{GM-CSF production by cultured synoviocytes}

We have recently observed that TNF-alpha $(1-100 \mathrm{ng} / \mathrm{ml})$ induces cultured synoviocytes to express the GM-CSF gene and secrete immunoreactive protein (Alvaro-Gracia, J. M., N. J. Zvaifler, and G. S. Firestein, submitted for publication). To test whether IFN-gamma inhibits GM-CSF production, RA synoviocytes (passage 3-7) from four separate donors were incubated for $48 \mathrm{~h}$ in the presence of medium, TNF-alpha, IFN-gamma, TNF-alpha plus IFN-gamma, IL-1 beta, or IL-1 beta plus IFN-gamma. GM-CSF was assayed in the supernatants by solid phase ELISA. TNF-alpha and IL-1beta alone induced GM-CSF production; IFN-gamma blocked only the effect of TNF-alpha (see Table VII).

\section{Discussion}

Most studies on the effects of cytokines on synoviocyte function have been concerned primarily with defining the activities of individual factors (13-21). However, it is now clear that these mediators function in concert in the synovium and that

Table VII. IFN-gamma Inhibition of TNF-alpha-induced GM-CSF Production by Cultured Synoviocytes

\begin{tabular}{lrrrr}
\hline & ST4 & ST5 & \multicolumn{1}{c}{ ST6 } & \multicolumn{1}{c}{ ST7 } \\
\hline Medium & $<5^{*}$ & $<5$ & $<5$ & $<5$ \\
TNF-alpha (100 ng/ml) & 260 & 122 & 164 & 1264 \\
IFN-gamma (100 U/ml) & $<5$ & $<5$ & $<5$ & $<5$ \\
TNF-alpha + IFN-gamma & $<5$ & $<5$ & $<5$ & 346 \\
IL-lbeta (100 U/ml) & 210 & 118 & ND & ND \\
IL-lbeta + IFN-gamma & 290 & 164 & ND & ND
\end{tabular}

$2 \times 10^{5}$ synoviocytes from four separate synovial tissues were cultured in $0.5 \mathrm{ml}$ medium with or without cytokine for $48 \mathrm{~h}$. Supernatants were harvested and assayed by ELISA.

* $\mathrm{pg} / \mathrm{ml}$ of GM-CSF. 
specific effects of a single cytokine depend on the presence (or absence) of other factors. For this reason, the major goal of this study was to identify and characterize cytokine interactions that might play a role in synovitis. The additive effects observed between IL-1 and TNF-alpha in our study were not surprising; these two proteins frequently enhance each other's function and even show synergy in fibroblast $\mathrm{PGE}_{2}$ production (32) or induction of rabbit experimental arthritis (33). However, the finding of mutual antagonism between TNF-alpha and IFN-gamma in four separate systems is novel and provocative. This phenomenon appears to be specific for TNF-alpha and IFN-gamma, since similar interactions were not observed between IL-1 and IFN-gamma in our study or in a recent study of proliferation and prostaglandin production by RA synoviocytes (34). The effect of other cytokines, including M-CSF, GM-CSF, IL-2, IL-3, and IL-4, on the stimulatory actions of IL-1beta, TNF-alpha, and IFN-gamma were also studied. None of them influenced synoviocyte HLA-DR expression, proliferation, or collagenase production. The lack of inhibition of IL-1 on HLA-DR expression differs from a previous study on rat synoviocytes in which IL-1 (but not TNF-alpha) blocked HLA-DR induction by IFN-gamma (35). The reason for the discrepancy is not known, but might reflect species differences.

The interactions between IFN-gamma and TNF-alpha on synoviocytes are striking, particularly in light of previous studies on other cell types in which IFN-gamma and TNF-alpha were either synergistic or additive. Examples of this phenomenon include the induction of HLA-DR molecules on a murine macrophage cell line (36) and various human tumor cell lines (37-39); induction of chemotactic peptide receptor expression on HL-60 cells (a human promyelocytic cell line) (40); induction of class I MHC molecules on human glioma tumor cells (41); induction of glycosaminoglycan synthesis by human lung fibroblasts (42); and increased production of collagen by dermal fibroblasts (43). TNF-alpha inhibits IFN-gamma-mediated induction of class II MHC molecules on human umbilical vein endothelial cells (44), but the fact that this combination is also cytotoxic on those cells (30) makes the interpretation of those data difficult. In contrast, we demonstrated that TNF-alpha and IFN-gamma inhibit each other's effect on cultured synoviocytes without cytotoxicity despite the fact that they both have stimulating effects when used independently. For instance, TNF-alpha significantly inhibits IFN-gamma-mediated HLA-DR induction, while IFNgamma blocks TNF-alpha-mediated synoviocyte proliferation, collagenase production, and GM-CSF production. The effect is not unique to cells isolated from RA synovium since OA synoviocytes behaved in a similar fashion.

The mechanism of TNF-alpha antagonism of IFNgamma-mediated HLA-DR induction is not known. Studies of HLA-DR mRNA expression in synoviocytes indicate that the inhibition is pretranslational, although it is not known whether changes in gene transcription or mRNA degradation are responsible. Prostaglandin synthesis was considered as a possible explanation (particularly because TNF-alpha is known to induce $\mathrm{PGE}_{2}$ production by synoviocytes [19]), but this is an unlikely explanation since indomethacin does not interfere with the inhibitory effects. Another potential inhibitory mechanism could be the modulation of the surface IFN-gamma receptor expression; however, preincubation of synoviocytes with TNF-alpha did not inhibit HLA-DR induction, suggest- ing that this is not the mechanism responsible for the inhibitory effect of TNF-alpha. Furthermore, in preliminary experiments with ${ }^{125}$ I-IFN-gamma, TNF-alpha does not downregulate specific IFN-gamma binding to cultured synoviocytes (unpublished data).

The data on HLA-DR expression on synoviocytes might provide some explanations for the distribution of this class II MHC antigen in the rheumatoid synovium. Although there is some disagreement, most evidence suggests that type B synoviocytes express little HLA-DR (considerably less than synovial macrophages and type A synoviocytes) $(22,45-47)$. We have recently shown that GM-CSF, which is present in the rheumatoid joint (28), plays a major role in macrophage HLA-DR and DQ expression in RA, possibly in combination with TNF-alpha (20). However, of the cytokines tested, only IFN-gamma induces HLA-DR on the fibroblast-like synoviocytes. Since only very small amounts of IFN-gamma are produced in the synovium $(23,48)$, it is not surprising, therefore, to find low surface HLA-DR expression on fibroblast-like synoviocytes. Furthermore, the small amount of IFN-gamma that is present is likely antagonized by TNF-alpha (10), hence contributing to the relative lack of class II MHC molecules on these cells.

The mechanism of IFN-gamma inhibition of TNF-alpha effects is also unknown. Although prostaglandins are known to inhibit synoviocyte proliferation $(14,17)$, experiments with indomethacin suggest that they are not involved. There is no information on TNF-alpha receptor modulation on synoviocytes, although in most cells studied IFN-gamma actually increases specific TNF-alpha surface binding (49-51). It seems unlikely that the inhibitory effect on TNF-alpha-induced proliferation reflects a generalized antiproliferative action by IFN-gamma $(52,53)$ since this cytokine alone did not inhibit synoviocyte proliferation. In fact, it modestly stimulated synoviocyte proliferation in some experiments, a phenomenon that has been described by others $(14,54)$, and did not interfere with IL-1-mediated synoviocyte proliferation. It is also unlikely that cytotoxicity or interactions with factors present in fetal calf serum account for the inhibitory effect (IFN-gamma also inhibited TNF-alpha-mediated proliferation of serum starved synoviocytes).

The observed in vitro antagonism between IFN-gamma and TNF-alpha suggests a novel homeostatic control mechanism. Since each cytokine interferes with the synoviocytestimulating effects of the other, their combined presence might be one method by which articular inflammation is normally attenuated. This could be particularly pertinent in RA where $T$ cells have a specific defect in IFN-gamma production (55). The RA synovium produces very little IFN-gamma and only very low levels are found in synovial effusions $(23,48)$. In contrast, large amounts of TNF-alpha can be detected in synovial effusions (10) and over 5\% of ST cells express the TNF-alpha gene (48). The absence of IFN-gamma under these circumstances could result in unopposed stimulation of fibroblast-like type B synoviocytes by TNF-alpha, leading to local proliferation, pannus formation, as well as GM-CSF and collagenase production. GM-CSF has been implicated in the activation of synovial macrophages (20) while collagenase is involved in matrix degradation in the joint. This hypothesis provides one possible explanation for the reported (albeit modest) efficacy of IFN-gamma in RA therapy $(56,57)$. Perhaps the benefits are limited because IFN-gamma, like GM-CSF, can induce class II 
MHC antigens on macrophages and does not antagonize the effects of IL-1, which is also present in high concentrations in the inflamed joint. A better understanding of these mechanisms might provide a rational basis for studying specific combinations of cytokines and inhibitors in the therapy of RA and other forms of chronic inflammatory arthritis.

\section{Acknowledgments}

The authors thank Raymond Breen and Dennis Young for technical assistance, and Drs. Richard Santore, Richard Coutts, and Richard Convery for providing many of the surgical specimens used in this study.

This work was supported in part by National Institutes of Health grants AR-14916, AR-39576, and CA-09174; and by grants from the Ministerio de Educación y Ciencia (Spain) and Sociedad Española de Reumatología.

\section{References}

1. Fassbender, H. G. 1975. Pathology of Rheumatic Diseases. Springer-Verlag, Berlin/Heidelberg. 79 pp.

2. Harris, E. D., A. M. Glauert, and A. H. G. Murley. 1977. Intracellular collagen fibers at the pannus-cartilage junction in rheumatoid arthritis. Arthritis Rheum. 20:657-665.

3. Krane, S. M. 1975. Collagenase production by human synovial tissues. Ann. NY Acad. Sci. 256:289-303.

4. Dayer, J. M., S. M. Krane, G. G. Russell, and D. R. Robinson. 1976. Production of collagenase and prostaglandins by isolated adherent rheumatoid synovial cells. Proc. Natl. Acad. Sci. USA. 73:945-949.

5. Dayer, J. M., D. R. Robinson, and S. M. Krane. 1977. Prostaglandin production by rheumatoid synovial cells. J. Exp. Med. 145:1399-1404.

6. Robinson, D. R., A. H. Tashjian, and L. Levine. 1975. Prostaglandin stimulated bone resorption by rheumatoid synovia. J. Clin. Invest. 56:1181-1188.

7. Wood, D. D., E. J. Ihrie, C. A. Dinarello, and P. L. Cohen. 1983. Isolation of an interleukin-1-like factor from human joint effusions. Arthritis Rheum. 26:975-983.

8. Nouri, A. M. E., G. S. Panayi, and S. M. Goodman. 1984. Cytokines in the chronic inflamation of rheumatic disease. I. The presence of interleukin-1 in synovial fluids. Clin. Exp. Immunol. 55:295-302.

9. Miossec, P., C. A. Dinarello, and M. Ziff. 1986. Interleukin-1lymphocyte chemotactic activity in rheumatoid arthritis synovial fluids. Arthritis Rheum. 29:461-470.

10. Saxne, T., M. A. Palladino, Jr., D. Heidegard, N. Talal, and F. A. Wollheim. 1988. Detection of tumor necrosis factor in rheumatoid arthritis synovial fluid and serum. Arthritis Rheum. 31:10411045.

11. Lafyatis, R., N. L. Thompson, E. F. Remmers, K. C. Flanders, N. S. Roche, S.-J. Kim, J. P. Case, M. B. Sporn, A. B. Roberts, and R. L. Wilder. 1989. Transforming growth factor-beta production from synovial tissues from rheumatoid patients and streptococcal cell wall arthritic rats: studies on secretion by synovial fibroblast-like cells and immunohistological localization. J. Immunol. 143:1 142-1148.

12. Hamerman, D., S. Taylor, I. Kirschenbaum, M. Klagsbrun, E. W. Raines, R. Ross, and K. A. Thomas. 1987. Growth factors with heparin binding affinity in human synovial fluid. Proc. Soc. Exp. Biol. Med. 186:384-389.

13. Dayer, J. M., S. R. Goldring, D. R. Robinson, and S. M. Krane. 1979. Effects of human mononuclear cell factor on cultured rheumatoid synovial cells. Interaction of prostaglandin $\mathrm{E}_{2}$ and cyclic adenosine 3', 5'-monophosphate. Biochim. Biophys. Acta. 586:87-105.
14. Butler, D. B., D. S. Piccoli, P. H. Hart, and J. A. Hamilton. 1988. Stimulation of human synovial fibroblast DNA synthesis by recombinant human cytokines. J. Rheumatol. 15:1463-1470.

15. Butler, D. M., T. Leizer, and J. A. Hamilton. 1989. Stimulation of human synovial fibroblast DNA synthesis by platelet-derived growth factor and fibroblast growth factor. Differences to the activation by IL-1. J. Immunol. 142:3098-3103.

16. Lafyatis, R., E. F. Remmers, A. B. Roberts, D. E. Yocum, M. B. Sporn, and R. Wilder. 1989. Anchorage-independent growth of synoviocytes from arthritic and normal joints: stimulation by exogenous platelet-derived growth factor and inhibition by transforming growth factor-beta and retinoids. J. Clin. Invest. 83:1267-1276.

17. Kumkumian, G. K., R. Lafyatis, E. F. Remmers, J. P. Case, S.-J. Kim, and R. Wilder. 1989. Platelet-derived growth factor and IL-1 interactions in rheumatoid arthritis. Regulation of synoviocyte proliferation, prostaglandin production and collagenase transcription. J. Immunol. 143:833-837.

18. Dayer, J. M., B. de Rochemonteix, B. Burrus, S. Demczuk, and C. A. Dinarello. 1986. Human recombinant interleukin 1 stimulates collagenase and prostaglandin $\mathrm{E}_{2}$ production by synovial cells. J. Clin. Invest. 77:645-648.

19. Dayer, J.-M., B. Beutler, and A. Cerami. 1985. Cachectin/ tumor necrosis factor stimulates collagenase and prostaglandin $\mathrm{E}_{2}$ production by human synovial cells and dermal fibroblasts. J. Exp. Med. 162:2163-2168.

20. Alvaro-Gracia, J. M., N. J. Zvaifler, and G. S. Firestein. 1989. Cytokines in chronic inflammatory arthritis. IV. Granulocyte/macrophage colony-stimulating factor-mediated induction of class II MHC antigen on human monocytes: a possible role in rheumatoid arthritis. J. Exp. Med. 170:865-875.

21. Amento, E. P., A. K. Bahn, K. G. McCullagh, and S. M. Krane. 1985. Influences of gamma interferon on synovial fibroblastlike cells. Ia induction and inhibition of collagen synthesis. J. Clin. Invest. 76:837-848.

22. Burmester, G. R., B. Jahn, P. Rohwer, J. Zacher, R. J. Winchester, and J. R. Kalden. 1987. Differential expression of Ia antigens by rheumatoid synovial lining cells. J. Clin. Invest. 80:595-604.

23. Firestein, G. S., and N. J. Zvaifler. 1987. Peripheral blood and synovial fluid monocyte activation in inflammatory arthritis. II. Low levels of synovial fluid and synovial tissue interferon suggest that gamma interferon is not the primary macrophage activating factor. Arthritis Rheum. 30:864-871.

24. Firestein, G. S., and N. J. Zvaifler. 1987. Down regulation of human monocyte differentiation antigens by gamma interferon. Cell. Immunol. 104:343-354.

25. Chomczynski, P., and N. Sacchi. 1987. Single-step method of RNA isolation by acid-guanidinium-thiocyanate-phenol-chloroform extraction. 1987. Anal. Biochem. 162:156-159.

26. Yoshioka, H., I. Oyamada, and G. Usuku. 1987. An assay of collagenase activity using enzyme-linked immunosorbent assay formammalian collagenase. Anal. Biochem. 166:172-177.

27. Brown, C. B., C. E. Hart, D. M. Curtis, M. C. Bailey, and K. Kaushansky. 1990. Two neutralizing monoclonal antibodies against human GM-CSF recognize the receptor bindind domain of the molecule. J. Immunol. 144:2184-2189.

28. Xu, W. D., G. S. Firestein, R. Taetle, K. Kaushansky, and N. J. Zvaifler. 1989. Cytokines in chronic inflammatory arthritis. II. Granulocyte-macrophage colony-stimulating factor in rheumatoid synovial effusions. J. Clin. Invest. 83:876-882.

29. Snyder, D. S., D. I. Beller, and E. R. Unanue. 1981. Prostaglandins modulate macrophages Ia expression. Nature (Lond.). 299:163166.

30. Baker, P. E., J. V. Fahey, and A. Munck. 1981. Prostaglandin inhibition of proliferation is mediated at two levels. Cell. Immunol. 61:52-64.

31. Stolpen, A. H., E. C. Guinan, W. Fiers, and J. S. Pober. 1986. Recombinant tumor necrosis factor and immune interferon act singly 
and in combination to reorganize human vascular endothelial cell monolayers. Am. J. Pathol. 123:16-24.

32. Elias, J. A., K. Gustilo, W. Baeder, and B. Freundlich. 1987. Synergistic stimulation of fibroblast prostaglandin production by recombinant interleukin-1 and tumor necrosis factor. J. Immunol. 138:3812-3816.

33. Henderson, B., and E. R. Pettipher. 1989. Arthritogenic actions of recombinant IL-1 and tumour necrosis factor alpha in the rabbit: evidence for synergistic interactions between cytokines in vivo. Clin. Exp. Immunol. 75:306-310.

34. Taylor, D. J., M. Feldman, J. M. Evanson, and D. E. Woolley. 1989. Comparative and combined effects of transforming growth factors alpha and beta, interleukin-1 and interferon-gamma on rheumatoid synovial cell proliferation, glycolisis and prostaglandin E production. Rheumatol. Int. 9:65-70.

35. Johnson, W. J., A. Kelley, J. R. Connor, B. J. Dalton, and P. C. Meunier. 1989. Inhibition of interferon-gamma-induced Ia antigen expression on synovial fibroblasts by IL-1. J. Immunol. 143:16141618.

36. Chang, R., and S. Lee. 1986. Effects of interferon-gamma and tumor necrosis factor on the expression of an Ia antigen on a murine macrophage cell line. J. Immunol. 137:2853-2856.

37. Arenzana-Seisdedos, F., S. C. Mogensen, F. Vuillier, W. Fiers, and J.-L. Virelizier. 1988. Autocrine secretion of tumor necrosis factor under the influence of interferon-gamma amplifies HLA-DR gene induction in human monocytes. Proc. Natl. Acad. Sci. USA. 85:60876091.

38. Kvale, D., P. Brandtzaeg, and D. Lovhaug. 1988. Up-regulation of the expression of secretory component and HLA molecules in a human colonic cell line by tumour necrosis factor-alpha and gammainterferon. Scand. J. Immunol. 28:351-357.

39. Pfizenmaier, K., P. Scheurich, C. Schluter, and M. Kronke. 1987. Tumor necrosis factor enhances HLA-A, B, C and HLA-DR gene expression in human tumor cells. J. Immunol. 138:975-980.

40. Rao, K. M., M. A. Misukonis, H. J. Cohen, and J. B. Weinberg. 1988. Cooperative effect of tumor necrosis factor and gamma-interferon on chemotactic peptide receptor expresion and stimulus-induced actin polymerization in HL-60 cells. Blood. 71:1062-1067.

41. Zuber, P., R. S. Acolla, S. Carel, A. C. Diserens, and N. de Tribolet. 1988. Effects of recombinant human tumor necrosis factoralpha on the surface phenotype and the growth of human malignant glioma cell lines. Int. J. Cancer. 42:780-786.

42. Elias, J. A., R. C. Krol, B. Freundlich, and P. M. Sampson. 1988. Regulation of human lung fibroblast glycosaminoglycan production by recombinant interferons, tumor necrosis factor, and lymphotoxin. J. Clin. Invest. 81:325-333.

43. Scharffetter, K., M. Heckmann, A. Hatamochi, C. Mauch, B. Stein, G. Riethmuller, H.-W. L. Ziegler-Heitbrock, and T. Kreig. 1989. Synergistic effect of tumor necrosis factor and interferon-gamma on collagen synthesis of human skin fibroblasts in vitro. Exp. Cell. Res. 181:409-419.
44. Leeuwenberg, J. F., J. Van Damme, T. Meager, T. M. Jeunhomme, and W. A. Buurman. 1988. Effects of tumor necrosis factor on the interferon-gamma-induced major histocompatibility complex class II antigen expression by human endothelial cells. Eur. J. Immunol. 18:1469-1472.

45. Iguchi, T., M. Kurosaka, and M. Ziff. 1986. Electron microscopic study of HLA-DR and monocyte/macrophage staining cells in the rheumatoid synovial membrane. Arthritis Rheum. 29:600-613.

46. Mapp, P. I., and P. A. Revell. 1988. Ultrastructural characterisation of macrophages (type A cells) in the synovial lining. Rheumatol. Int. 8:171-176.

47. Burmester, G. R., A. Dimitriu-Bona, S. J. Waters, and R. J. Winchester. 1983. Identification of three major synovial lining cell populations by monoclonal antibodies directed to Ia antigens and antigens associated with monocytes/macrophages and fibroblasts. Scand. J. Immunol. 17:69-82.

48. Firestein, G. S., J. M. Alvaro-Gracia, and R. Maki. 1990. Quantitative analysis of cytokine gene expression in rheumatoid arthritis. J. Immunol. 144:3347-3353.

49. Ruggiero, V., J. Tavernier, W. Fiers, and C. Baglioni. 1986. Induction of the synthesis of tumor necrosis factor receptors by interferon-gamma. J. Immunol. 136:2445-2450.

50. Tsujimoto, M., Y. K. Yip, and J. Vilcek. 1986. Interferongamma enhances expression of cellular receptors for tumor necrosis factor. J. Immunol. 136:2441-2444.

51. Aggarwal, B. B., T. E. Eessalu, and P. E. Hass. 1985. Characterization of receptors of human tumour necrosis factor and their regulation by gamma-interferon. Nature (Lond.). 318:19-26.

52. Pestka, S., J. A. Langer, K. C. Zoon, and C. E. Samuel. 1987. Interferons and their actions. Annu. Rev. Biochem. 56:727-777.

53. Warner, S. J. C., G. B. Friedman, and P. Libby. 1989. Immune interferon inhibits proliferation and induces 2 '-5'-oligoadenylate synthetase gene expression in human vascular smooth muscle cells. $J$. Clin. Invest. 83:1174-1182.

54. Brinckerhoff, C. E., and P. M. Guyre. 1985. Increased proliferation of human synovial fibroblasts treated with recombinant immune interferon. J. Immunol. 134:3142-3146.

55. Hasler, F., H. G. Bluestein, N. J. Zvaifler, and L. B. Epstein. 1983. Analysis of the defects responsible for the impaired regulation of Epstein-Barr virus-induced B cell proliferation by rheumatoid arthritis lymphocytes. I. Diminished gamma interferon production in response to autologous stimulation. J. Exp. Med. 157:173-188.

56. Lemmel, E. M., D. Brackertz, M. Franke, W. Gaus, P. W. Hartle, K. Machalke, H. Mielke, H. J. Obert, H. H. Peter, J. Sieper, et al. 1988. Results of a multicenter placebo-controlled double-blind randomized phase III clinical study of treatment of rheumatoid arthritis with recombinant interferon-gamma. Rheumatol. Int. 8:87-93.

57. Cannon, G. W., R. D. Emkey, A. Denes, S. A. Cohen, P. A. Saway, F. Wolfe, A. M. Jaffer, A. L. Weaver, L. Cogen, J. Julinello, et al. 1990. Prospective two-year followup of recombinant interferongamma in rheumatoid arthritis. J. Rheumatol. 17:304-310. 